\title{
$13: 50538143-50466770$
}

National Cancer Institute

\section{Source}

National Cancer Institute. 13:50538143-50466770. NCI Thesaurus. Code C42449.

Physical location of GUCY1B2_Gene 